\title{
NORMA WZORCOWA VS NORMA UŻYTKOWA A GLOTTODYDAKTYKA
}

\begin{abstract}
Słowa kluczowe: norma wzorcowa, norma użytkowa, poprawność językowa, podręczniki do nauczania języka polskiego jako obcego

Streszczenie. W artykule został przedstawiony problem normy wzorcowej w opozycji do normy użytkowej w nauczaniu języka polskiego jako obcego (jpjo). Analiza kilku, losowo wybranych podręczników do nauczania jpjo pokazuje, że norma realizowana jest tam rozmaicie. Stąd postulat, aby zagadnienie to poddać szerszej refleksji glottodydaktycznej i zastanowić się nad rolą obu norm w nauczaniu jpjo.
\end{abstract}

Zagadnienie błędów, i to każdego typu, łączy się nierozerwalnie z kwestią normy - wszak już najprostsza, słownikowa definicja ujmuje błąd jako: 'odstępstwo od normy; pomyłka' (USJP). Pytanie, które od razu się nasuwa, dotyczy pojmowania normy - ten sam słownik definiuje ją następująco: 'ustalona, ogólnie przyjęta zasada; reguła, przepis, wzór' (USJP). Rzecz jasna, jest to podejście ogólne, a zarówno błąd, jak i norma wymagają doprecyzowania w postaci przydawki klasyfikującej. I tak możemy mówić np. o błędzie merytorycznym, rzeczowym, gramatycznym, maszynowym itp. Mniejszy zakres użycia ma norma - moralna, etyczna, ortograficzna, ale nie maszynowa czy rzeczowa. Odrębne zjawisko stanowi błąd glottodydaktyczny². Pojęcie to obejmuje swoim zasięgiem zarówno błędy metodyczne, etyczne, merytoryczne, jak i językowe itp. Trudno jednoznacznie przeciwstawić mu pojęcie normy glottodydaktycznej, choć, o czym będzie jeszcze mowa, może należałoby dokonać takiego zestawienia. W niniejszym artykule przedmiot zainteresowania stanowi norma językowa, a także norma glottodydaktyczna. Celem jest analiza wybranych podręczników pod kątem realizacji normy wzorcowej i/ lub normy użytkowej, a także próba

\footnotetext{
${ }^{1}$ beatag@uni.lodz.pl; Katedra Lingwistyki Stosowanej i Kulturowej, Wydział Filologiczny, Uniwersytet Łódzki, 90-236 Łódź, ul. Pomorska 171/173.

${ }^{2}$ Szczegółowe rozważania dotyczące błędu glottodydaktycznego, w tym przegląd literatury przedmiotu, odnaleźć można w książce R. Kalety Polsko-białoruska lapsologia glottodydaktyczna (2015).
} 
oceny przydatności obu norm w aspekcie glottodydaktycznym. Zanim jednak pokazane zostaną konkretne przykłady, należy przyjrzeć się bliżej pojęciu normy językowej.

\section{NORMA JEZYKOWA}

Mirosław Bańko w artykule zatytułowanym $O$ normie $i$ błędzie porównuje trzy podejścia do normy językowej: „Pierwsze z nich nie znosi relatywizmu: coś jest albo nie jest błędem (...). Drugie zakłada stopniowanie błędów: są błędy drobne, tolerowane w pewnych okolicznościach, i błędy poważne, nie do zaakceptowania. Trzecie wynika z przekonania, że coś może jednocześnie być i nie być błędem, zależnie od punktu widzenia" (Bańko 2008, 3). Ta wielorakość w ujmowaniu zjawiska błędu pokazuje, że często ma on charakter relatywny, podlega subiektywnej ocenie. Zwraca na to uwagę także Zofia Kaleta, która pisze o „subiektywności oceny normatywności struktur językowych z jednej strony i zachowawczym charakterze normy z drugiej” (Kaleta 1995, 87). Wynika stąd konieczność zdefiniowania samego pojęcia normy.

Przegląd definicji normy rozpocznijmy od ujęcia specjalistycznego, glottodydaktycznego, dzięki któremu zrozumiemy rolę normy w nauczaniu języków obcych. Podręczny stownik językoznawstwa stosowanego rejestruje następującą definicję normy językowej: „te wszystkie elementy w mowie, które nie są bezpośrednio dystynktywne, aczkolwiek uznawane są społecznie za poprawne. Tak więc normę językową należy rozumieć jako zgodną z powszechną $\mathrm{w}$ danej wspólnocie komunikatywnej realizację określonego systemu językowego (...). Do pełnej kompetencji językowej należy określone poczucie normy, które jest na ogół silniejsze dla języka pisanego niż mówionego" (Szulc 1984, s. 167). Warto zwrócić uwagę na fakt, że poczucie normy językowej należy do kompetencji językowej, a odpowiednie jej ukształtowanie to główny cel nauczania języków obcych. Zatem norma językowa musi zaistnieć w procesie glottodydaktycznym - pytanie, czy wyrażona implicytnie, czy eksplicytnie, pozostawiam na razie otwarte.

W językoznawstwie ogólnym pojęcie normy pojawiło się dość późno. Przez lata uważano bowiem za wzorcowy język literacki, a także język wykształconej warstwy społeczeństwa i w odniesieniu do niego określano poprawność językową (por. Szober 1937, s. XI). Bodaj jako pierwsza normę językową zdefiniowała Halina Kurkowska, ujmując ją jako: ,zbiór zaaprobowanych przez dane społeczeństwo jednostek językowych oraz reguł określających zasięg realizacji związków między tymi jednostkami w tekstach" (Buttler, Kurkowska, Satkiewicz 1971, s. 18). Podobne ujęcie odnaleźć można w późniejszych pracach, m.in. Danuty 
Buttler (1985a), Jana Miodka (2001), Andrzeja Markowskiego (2005). Warto zacytować w tym miejscu słowa J. Miodka, który uważa, że: „Pojęcie normy językowej ma znaczenie nie tylko teoretyczne, ale przede wszystkim praktyczne. Nawiązują do niego - świadomie lub nieświadomie - wszyscy użytkownicy języka, gdy zaczynają się zastanawiać nad wyborem odpowiednich środków wyrażenia myśli" (Miodek 2001, s. 73).

Już w 1977 roku, czyli sześć lat po opublikowaniu pierwszej definicji normy, H. Kurkowska opowiedziała się za zróżnicowaniem normy, proponując jej trzy poziomy: potoczno-użytkowy, polszczyzny publicznej, wzorcowy (Kurkowska 1977, s. 17-25). Należy zwrócić uwagę, że kryterium podziału stanowi tu stopień uczestnictwa w języku, a zatem mamy do czynienia z ujęciem socjolingwistycznym. Jest to o tyle istotne, że poziom uczestnictwa w języku osoby uczącej się go jako języka obcego jest bardzo zróżnicowany, w dużej mierze zależny od reprezentowanego poziomu biegłości językowej. Nie może być jednak utożsamiany z poziomem uczestnictwa natywnego użytkownika języka. Na potrzebę wyróżnienia dwóch poziomów normy zwracała także uwagę D. Buttler, która uznała, że praktyka językowa osób mówiących po polsku pozwala wskazać normę spontaniczną, naturalną w opozycji do normy skodyfikowanej (Buttler 1985b, s. 20). Przez lata owe propozycje pozostawały postulatami. Do zróżnicowania normy językowej doszło bowiem dopiero w roku 1999, kiedy to ukazał się Nowy słownik poprawnej polszczyzny, wprowadzający normę wzorcową i użytkowąa . Ta podwójna norma jest szczególnie istotna dla poczynionych tu analiz, dlatego przyjrzyjmy się jej dokładniej. Norma wzorcowa obejmuje „te elementy języka i wypowiedzi, które są używane świadomie, z poczuciem ich wartości semantycznej i stylistycznej, a pozostają $\mathrm{w}$ zgodzie $\mathrm{z}$ tradycją językową, regułami gramatycznymi i semantycznymi polszczyzny oraz tendencjami rozwojowymi, które można w niej obserwować" (Markowski 2005, s. 32). Zaleca się, aby norma ta dotyczyła wszystkich wystąpień oficjalnych oraz starannej odmiany polszczyzny nieoficjalnej. Mowa tu o mediach, języku polityki, a także dydaktyki szkolnej. Z kolei norma użytkowa „obejmuje zbiór wyrazów, ich form, połączeń, używanych w kontaktach swobodnych, nieoficjalnych, o różnorodnej tematyce. Chodzi o zespół środków językowych charakterystycznych przede wszystkim dla tych typów kontaktów, w których język traktuje się jako narzędzie przekazu informacji, perswazji itd." (Markowski 2005, s. 34). Norma ta jest wewnętrznie zróżnicowana i można w niej wyróżnić normę: profesjonalną, potoczną regionalną, potoczną ogólną.

${ }^{3}$ M. Bańko zwraca uwagę na nietrafność obu nazw - ,sugerują hierarchizację, ale nie wskazują jej źródła” (Bańko 2008, 7). Podobnie określenia synonimiczne - norma wysoka i potoczna - ,sugerują, że podstawą rozdzielenia norm było kryterium socjolingwistyczne, mianowicie stopień oficjalności wypowiedzi" (Bańko 2008, 7). Tymczasem norma profesjonalna, stanowiąca składnik normy użytkowej/ potocznej, należy do polszczyzny oficjalnej. 
$\mathrm{Na}$ koniec rozważań nad normą językową zastanówmy się nad jej rolą. D. Buttler wskazała na trzy funkcje normy: realizacyjną, polegająca na decydowaniu o tym, które modele systemowe zostaną wypełnione materiałem leksykalnym, a które nie; selekcyjną - systemowe struktury języka przechodzą przez filtr normy i zostają dopuszczone lub nie do obiegu; rozdzielczą (dystrybucyjną) - elementy normy występujące jako realizacja alternatywnych wzorów systemu uzyskują na poziomie normy zróżnicowanie semantyczne lub stylistyczne (por. Buttler 1985a, s. 12-15).

W tym miejscu należy zadać kluczowe dla niniejszych rozważań pytanie: jaka norma - wzorcowa czy użytkowa - jest reprezentowana w podręcznikach do nauczania języka polskiego jako obcego. Aby na nie odpowiedzieć, przeprowadzono krótką analizę wybranych losowo podręczników do nauczania jpjo, wydanych po 1999 roku $^{4}$.

Podręcznik uznawany jest za odrębny gatunek, przynależący do dyskursu dydaktycznego. Posiada on cechy tekstu naukowego lub popularnonaukowego, ale materiał opracowany jest i przedstawiony zgodnie z zasadami dydaktyki. Trzy podstawowe cechy determinujące kształt podręcznika to: „treść - zasób informacji poznawczych, które powinny zostać przekazane w tekście odbiorcy, oraz specyficzny odbiorca - występujący tu w roli ucznia, cechujący się określonym zasobem nabytej już wiedzy i poziomem kompetencji językowej; trzeci czynnik ma charakter funkcjonalny" (Nocoń 2009, s. 44). W podręcznikach do nauczania jpjo treść obejmuje warstwę semantyczną i gramatyczną języka, uzależnioną od poziomu nauczania. Aspekt funkcjonalny to pomoc w osiągnięciu odpowiedniego poziomu biegłości językowej. Najistotniejszy wydaje się trzeci element - odbiorca. Jest to najczęściej obcokrajowiec, który z różnych powodów chce nauczyć się języka polskiego. Proces uczenia się może przebiegać, co istotne, bądź w środowisku językowym uczącego się, czyli poza granicami naszego kraju, bądź na gruncie polskim - wówczas uczący się „otoczony” jest polszczyzną omal przez całą dobę. Podręczniki jednak nie są dedykowane osobom uczącym się języka w Polsce w opozycji do osób uczących się go w świecie ${ }^{5}$. To zróżnicowanie miejsca uczenia się języka łączy się bezpośrednio z normą językową. Dla osób uczących się polszczyzny za granicą jedynym wyznacznikiem poprawności staje się podręcznik oraz lektor. W przypadku uczących się w Polsce normę podręcznikową weryfikuje kontakt z żywym, codziennym językiem potocznym.

\footnotetext{
${ }^{4}$ Wcześniej obowiązywała tylko jedna norma i wszelkie odstępstwa od niej były uznawane za błąd językowy.

${ }^{5}$ Co prawda mamy podręczniki adresowane do konkretnych grup językowych (por. np. Malota 2009, Skorupa, Lipińska 2010), jednak nie oznacza to, że są one przeznaczone do uczenia jpjo za granicą.
} 
Poniżej przedstawiono kilka zagadnień językowych (z zakresu wymowy, gramatyki oraz leksyki ${ }^{6}$ ) objętych ową podwójną normą. Posłużono się przykładami pochodzącymi z podręczników do nauczania jpjo, które każdorazowo opatrzono komentarzem poprawnościowym. Należy zaznaczyć, że badania nie miały charakteru diagnostycznego - nie uwzględniono w nich reprezentatywnej próby tekstów podręcznikowych. Należałoby raczej mówić o selektywnym i subiektywnym doborze materiału. Celem nie jest bowiem analiza podręczników, lecz ukazanie problemu, jakim jest podejście do normy językowej w nauczaniu języka polskiego jako obcego.

\section{POPRAWNOŚĆ FONETYCZNA}

\section{Odstępstwa od akcentu paroksytonicznego}

Zgodnie z normą wzorcową istnieje grupa wyrazów, w których akcent pada na trzecią sylabę (akcent proparoksytoniczny) bądź na czwartą sylabę od końca. Informację o tym odnajdujemy m.in. w książce Odkrywamy język polski. Gramatyka dla uczacych (się) języka polskiego jako obcego (Madelska, Warchoł-Schlottmann 2008). Ponieważ większość popularnych podręczników kursowych nie uwzględnia opisu wymowy, za materiał badawczy uznałam nagrania zawarte na płytach dołączonych do podręczników. I tak w serii Start. Survival Polish (Dembińska, Małyska 2013) konsekwentnie stosuje się akcent paroksytoniczny - m.in. w wyrazach zakończonych na -yka, -ika, jak fonetyka, czy w liczebnikach typu czterysta, osiemset. Mamy więc do czynienia z realizacją normy użytkowej. Odmiennie na tym tle prezentuje się podręcznik Polski, krok po kroku. Tu we wspomnianych formach, a także w czasownikach liczby mnogiej czasu przeszłego pojawia się akcent proparoksytoniczny, np. zrobilyśmy, chcialyśmy (s. 161); siedemset, dziewięćset (s. 49). Podobnie w serii Hurra po polsku 1 -czterysta trzydzieści; osiemset dwadzieścia (s. 52). W podręczniku tym przy omawianiu form czasu przeszłego $\mathrm{z}$ akcentem proparoksytonicznym pojawia się nawet ćwiczenie poświęcone temu zagadnieniu (s. 87).

Właściwa, tzn. zgodna z normą wzorcową akcentuacja pomaga zrozumieć sposób tworzenia aglutynacyjnych form czasu przeszłego czasowników, czy też form złożonych liczebników. Wydaje się, że dzięki temu łatwiej uczącym się języka polskiego jako obcego przyswoić zagadnienia morfologiczne. Niestety, jest to niemożliwe, a może raczej pozbawione sensu w sytuacji, gdy stosuje się akcent na drugą sylabę od końca (choć jest to wymowa zgodna z normą użytkową).

\footnotetext{
${ }^{6}$ Świadomie wybrano zjawiska reprezentujące trzy różne obszary języka.
} 


\section{POPRAWNOŚĆ GRAMATYCZNA}

\section{Biernik liczby pojedynczej rzeczowników męskonieżywotnych}

Do normy wzorcowej należy zerowa końcówka biernika rzeczowników męskonieżywotnych (jem kotlet, kroję ogórek), natomiast norma użytkowa dopuszcza końcówkę - $a$ w przypadku niektórych rzeczowników (jem kotleta, kroję ogór$k a$ ). W większości podręczników nie ma informacji dotyczących rozróżnienia obu form. Chlubny wyjątek stanowi podręcznik Haliny Goszczyńskiej i Mirosławy Magajewskiej, w którym odnajdujemy informację dotyczącą zróżnicowania normy w tym zakresie: „W nazwach niektórych potraw, słodyczy, owoców, warzyw i kwiatów (np. krokiet, paczek, banan, pomidor, narcyz) biernik może być równy dopełniaczowi (w polszczyźnie potocznej, kolokwialnej) lub może być taki sam jak mianownik (w polszczyźnie starannej, normatywnej)" (Goszczyńska, Magajewska 2012, 68). Autorki prezentują także zestawienie zdań zgodnych z normą użytkową w opozycji do normy wzorcowej, np. Ugotowałam dużego kalafiora. vs Ugotowałam duży kalafior. Pozostałe podręczniki podchodzą do tego zagadnienia dość swobodnie. Po pierwsze, nie pojawia się informacja o podwójnej normie. Po drugie, często w obrębie tego samego podręcznika stosowane są obie normy, co uzależnione jest od konkretnego rzeczownika. I tak na przykład w książce Polski, krok po kroku w części rzeczowników męskonieżywotnych stosuje się końcówkę zerową, czyli biernik równy jest mianownikowi (norma wzorcowa): poprosze (...) filet drobiowy z grilla (s. 65), a kilka stron dalej, w tej samej jednostce lekcyjnej, pojawia się zdanie: Mam zielonego banana (s. 68), które mieści się jedynie w normie użytkowej. Niestety, nie towarzyszy temu żaden komentarz, który thumaczyłby tę niekonsekwencję deklinacyjną. Wydaje się, że w całym podręczniku częstszy jest biernik równy dopełniaczowi, a zatem dominuje norma użytkowa (nie tylko w odniesieniu do grup rzeczowników wymienionych przez Goszczyńską i Magajewską, ale także innych, o dużej frekwencji użycia, np. potoczne Czekam jeszcze na SMS-a (s. 69), zamiast wzorcowego Czekam jeszcze na SMS). Z kolei w podręczniku Hurra!!! Po polsku 1 dość konsekwentnie stosowana jest norma wzorcowa, np. Jem (...) kotlet z ziemniakami (s. 51); Poproszę (...) na drugie danie ziemniaki i kotlet schabowy z kapusta (s. 57).

I jeszcze jeden przykład - bądź błędnie utworzonego biernika rzeczownika ząb (rzeczownik męskonieżywotny, zatem $\mathrm{M}=\mathrm{B}$ ), bądź błędnej rekcji czasownika używać (kogo, co - rekcja biernikowa):

Ojej, a może lepiej usunać tego zęba? (Stempek i in., 2013, s. 169)

O ile we wcześniej omówionych przykładach norma użytkowa dopuszczała biernik równy dopełniaczowi, o tyle tu słowniki poprawnościowe wyraźnie zaznaczają 'ząb $m I V, D$. zęba, $B$. ząb (nie: zęba)' (NSPP). Zdanie to nie mieści się zatem ani w normie wzorcowej, ani w użytkowej. 


\section{POPRAWNOŚĆ LEKSYKALNA}

Leksyka jest najbardziej dynamicznie zmieniającą się warstwą języka. Powodem tego stanu rzeczy jest zarówno szybko zmieniająca się rzeczywistość pozajęzykowa, jak i moda językowa, która powoduje dużą popularność pewnych słów.

W wielu podręcznikach do nauczania jpjo, zwłaszcza na poziomie A1, pojawiają się internacjonalizmy, które nie obciążają zbytnio studentów kwestiami semantycznymi, a służą jako baza do wprowadzania zagadnień gramatycznych. Bardzo często wyrazy te zaliczają się do normy użytkowej, jak np. mailować, czy surfować (Małolepsza, Szymkiewicz 2010, s. 48). I choć czasowniki te nie mają swoich odpowiedników w normie wzorcowej, to możliwe jest zastąpienie ich formami opisowymi: wysyłać listy elektroniczne, korzystać z internetu (przeglądać strony internetowe).

Inne zagadnienie z zakresu poprawności leksykalnej dotyczy stosowania form potocznych używanych $w$ dialogach. Zarysowuje się tu ciekawe zjawisko mieszania $\mathrm{w}$ jednym tekście słownictwa wysokiego z leksyką potoczną, użytkową. Znakomitym przykładem może być fragment lekcji 25. z podręcznika Polski, krok po kroku dotyczący wizyty u lekarza. Oto wybrane fragmenty tego tekstu:

A więc proszę go zażywać 3 razy dziennie przez 7 dni. Proszę leżeć w łóżku, dużo pić i odpoczywać. Czy potrzebuje pan zwolnienia z pracy?

Nie, jestem studentem, nie pracuję. Kiedy mam przyjść do kontroli? (Stempek i in., 2013, s. 169)

W USJP czasownik zażywać opatrzony jest kwalifikatorem książkowe i zdefiniowany jako 'wprowadzać do organizmu lek, narkotyk, truciznę, połykając je, pijąc', z kolei rzeczownik kontrola oznacza 'sprawdzanie, badanie czegoś' (USJP), jednak połączenie przyjść do kontroli w znaczeniu 'przyjść na wizytę kontrolną' jest formą potoczną. Dodatkowo wyrażenie: zwolnienie z pracy jest wieloznaczne, rozumiane kontekstowo, choć wystarczyłoby zmienić je na zwolnienie lekarskie, aby ową dość niefortunną polisemiczność zlikwidować.

\section{NORMA WZORCOWA CZY NORMA UŻYTKOWA?}

Zaprezentowane powyżej przykłady miały na celu zilustrowanie problemu, przed którym, moim zdaniem, staje nauczyciel jpjo - jakiej normy nauczać: użytkowej, wzorcowej, a może obu? Zanim podzielę się swoimi uwagami na ten temat, chciałabym przywołać artykuł Magdaleny Steciąg, który w dużej mierze stanowił inspirację do podjętych tu rozważań. W tekście zatytułowanym Kim jest językoznawca normatywista dziś? (Steciąg 2014) badaczka podjęła próbę scha- 
rakteryzowania postaw współczesnych językoznawców polonistów wobec poprawności językowej. Użyła do tego trzech metafor, bardzo trafnie obrazujących owe postawy:

\section{ORĘDOWNIK-AUTORYTET-PROPAGATOR}

2. PRZEWODNIK-KONTROLER-OBSERWATOR

3. STRAŻNIK-OGRODNIK-SĘDZIA (Steciąg 2014, 18)

Przyjrzyjmy się krótko tym portretom. Orędownik to osoba, która propaguje językoznawstwo pedagogiczne, naucza wszystkich o poprawnych formach z perspektywy znawcy. Bardzo często staje się/ jest autorytetem w dziedzinie poprawności językowej, a dzięki działalności medialnej, pisarskiej, publicystycznej także jej propagatorem. Drugi szereg wyodrębniony został ze względu na samo podejście do normy. Do jego opisu M. Steciąg stosuje metaforę autobusu. Pierwszy wizerunek to ,przewodnik w autobusie wycieczkowym, który dba o jak najlepsze funkcjonowanie języka jako narzędzia komunikacji językowej” (Steciąg 2014, s. 21-22). Normatywisty kontrolera dotyczy metafora autobusu miejskiego, w którym sprawdza on poprawność, dyskwalifikując błędne formy. Dla obserwatora zaś najważniejszy jest uzus i to co powszechne, uznaje on za dobre. Ostatni zestaw portretów odnosi się do strażników poprawności językowej, którzy uważają swą pracę za niesienie kaganka oświaty, ogrodnika, „uprawiającego język" i niegodzącego się na jego zbyt szybki i niekontrolowany rozwój i wreszcie sędzia, który ocenia, co w języku dobre, a co nie (Steciąg 2014, s. 25-26).

Sądzę, że część z tych metafor można odnieść do nauczyciela języka polskiego jako obcego - choć nie są oni raczej normatywistami ex definitione, to jednak występują w roli ogrodników uprawiających nauczanie języka polskiego jako obcego. Mogą przybrać oblicze sędziego, który ogranicza swą działalność do wydawania wyroków: dobrze, źle; mogą stać się strażnikami stojącymi na straży poprawności językowej stawianej ponad wszystko. Nie są to jednak, moim zdaniem, postawy pożądane. Bez wątpienia nauczyciel jpjo powinien być dla sowich uczniów autorytetem językowym - pamiętajmy, że bywa on jedynym rodzimym użytkownikiem języka, z którym mają kontakt uczący się. Ważne, by był przewodnikiem objaśniającym zawiłe meandry polszczyzny, dbając przy tym, by język był jak najlepszym narzędziem komunikacji dla osób uczących się. Nie obca powinna być mu również postawa obserwatora uczulonego na zmiany $\mathrm{i}$ tendencje językowe. Mówiąc bez metafor - nauczyciel języka polskiego jako obcego powinien swoją postawą reprezentować normę językową - w moim odczuciu - wysoką. Niestety, analiza podręczników pokazuje, że tak nie jest. Oczywiście zdaję sobie sprawę z nastawienia komunikacyjnego, z założenia zmierzającego do opanowania języka tak, by umożliwiał on swobodną komunikację, zbliżoną do rodzimych użytkowników języka, ale czy to znaczy, że nie możemy uczyć form poprawnych? Pozwolę sobie przytoczyć tu krótką historię, która spotkała 
mnie kilka lat temu. Jedna z moich uczennic, Niemka, która na niemieckim uniwersytecie ukończyła filologię słowiańską z językiem polskim jako językiem A, nie mogła zrozumieć, dlaczego Polacy dodają końcówkę $-a \mathrm{w}$ bierniku niektórych rzeczowników męskonieżywotnych - argumentowała, że jest to działanie pozbawione sensu, łatwiej bowiem nauczyć się bezwyjątkowej reguły, według której biernik rzeczowników męskonieżywotnych równy jest mianownikowi niż zastanawiać się nad doborem końcówki: zerowej lub - $a$. Co więcej, jej argumenty przekonały uczonych przez nią studentów filologii germańskiej, którzy przyznali jej rację i starali się stosować normę wysoką. Jeżeli jednak podręczniki preferują normę użytkową, to od razu stawiają uczącego się w trudniejszej, w mojej opinii, sytuacji. Uwaga ta odnosi się również do innych zjawisk - obcokrajowcy są często lepszymi, tzn. zgodnymi z normą wysoką, użytkownikami języka polskiego niż jego rodzimi użytkownicy. Co prawda J. Nocoń wskazuje na upotocznienie języka podręcznika jako jeden z elementów, który ma przyciągnąć uczniów do książki (Nocoń 2009, 216), ale w przypadku obcokrajowców bardzo łatwo ten argument obalić - oni znają, przynajmniej na początku, tylko taki język, jaki zaoferuje im podręcznik i nauczyciel - nie ocenią zatem jego atrakcyjności pod kątem potoczności.

Nie chcę, aby czytelnik tego artykułu sądził, że reprezentuję postawę puryzmu językowego. Daleka jestem od tego. Postuluję jednak, by uczący się języka polskiego jako obcego mieli szansę na poznanie normy wzorcowej - czy ją będą realizować, czy też bliższa będzie im norma użytkowa, to rzecz wtórna. Normy wzorcowej nie należy również odnosić do oceny wypowiedzi uczących się języka polskiego jako obcego.

Ciekawie na tle powyższych rozważań prezentuje się stanowisko Jerzego Podrackiego (2010), który w artykule Poziomy normy językowej w nauczaniu języka polskiego jako obcego (JPJO) zaprezentował miejsca wariantywne w polszczyźnie (w zakresie składni, fleksji, leksyki, frazeologii i wymowy) istotne ze względu na proces glottodydaktyczny. Badacz postuluje, aby w większości zaprezentowanych przez niego przypadków (np. przy fleksji czasowników mleć, pleć) odwoływać się raczej do normy użytkowej, gdyż rozstrzygnięcia normy wzorcowej są tu zbyt rygorystyczne (Podracki 2010, 144). Jednocześnie J. Podracki podkreśla, że „,W nauczaniu JPJO (...) pojęcie normy językowej (...) wydaje się niezbędne (...), a jej zróżnicowanie powinno być wyjaśniane i ilustrowane przykładami już od poziomu B2" (Podracki 2010, 144).

Być może pewnym rozwiązaniem jest wprowadzenie zamiast normy językowej normy glottodydaktycznej, wielokrotnie definiowanej w pracach z zakresu glottodydaktyki (por. m.in. Grucza 1978, Korzeniewska-Rogalewicz 1986). Ujmowana jest ona różnie, jednak za najbardziej reprezentatywną należy uznać definicję Krystyny Chomicz-Jung: „zbiór parametrów treści glottodydaktycznych zmieniających się $\mathrm{w}$ toku procesu nauczania, uczenia się i przyswajanie języka 
obcego" (Chomicz-Jung 1990, s. 24). Widać tu nastawienie praktyczne, nakierowanie na uczącego się, a norma ma być wypracowywana w interakcjach między nauczycielem a uczniami. Potwierdzenie takiej interpretacji odnajdujemy m.in. w artykule Jana Mazura, który pisał: „Problem normy językowej na tych terenach [kraje byłego ZSRR - B.G.] to osobne zagadnienie wymagające szybkiego działania. W sytuacjach dużego zróżnicowania społecznego i wytworzenia się skomplikowanych wspólnot komunikacyjnych określenie zasobu norm dla polszczyzny na Wschodzie jest ze względu na rozwój szkolnictwa polskiego i odradzające się zainteresowanie językiem polskim bezwzględnie konieczne" (Mazur 1995, 238). Widać tu wyraźny postulat stworzenia wyznaczników poprawności dla polszczyzny używanej na Wschodzie - byłyby to normy wypracowane w kontaktach nauczycieli z Polski z Polakami na Wschodzie. Ich polszczyzna była bowiem przez lata wyizolowana, a to powoduje brak rozwoju języka i determinuje jego kształt. Jednak przy analizie materiału zawartego w podręcznikach, trudno mówić o normie interakcyjnej, tu norma glottodydaktyczna pozostawałaby w zgodzie z normą ogólnojęzykową, uwzględniając z jednej strony częstotliwość użycia, czyli normę użytkową, z drugiej zaś systemowość, która, moim zdaniem, jest dla uczących się dużo łatwiejsza do opanowania niż niezliczone wyjątki. Koncepcja ta pozostawałaby w zgodności z propozycją Anny Dąbrowskiej i Małgorzaty Pasieki, które uznały, że: „Błędy popełniane przez cudzoziemców tylko częściowo jednak pokrywają się z błędami rodzimych użytkowników języka" (Dąbrowska, Pasieka 2008, s. 103), a zatem typologia błędów przyjęta dla Polaków jest nieadekwatna do typów błędów popełnianych przez osoby uczące się języka polskiego jako obcego. Na zakończenie rozważań autorki postulują wprowadzenie kategorii błędu pragmatycznego, obejmującego błędy typu „Polak by tak nie powiedział/nie napisał", a także nadbłędy - konstrukcje a- lub dysmorficzne, bełkot (Dąbrowska, Pasieka 2008, s. 103). Przy takim podejściu owa podręcznikowa norma glottodydaktyczna, którą można by również określić pragmatyczną, byłaby elementem niekodyfikowanym, ale ustalanym, budowanym w praktyce. Łącząc oba podejścia do normy glottodydaktycznej (interakcyjne i podręcznikowe), należałoby postulować, aby uczący się mógł wybrać formę dla niego dogodniejszą, spośród tych, które mieszczą się w obrębie normy językowej. Jest to koncepcja, która może wydawać się utopijna, wymaga bowiem ogromnej świadomości językowej od uczących się, jednak wydaje mi się, że często nie doceniamy wrażliwości językowej naszych uczniów. Poza tym należy pamiętać o jeszcze jednej kwestii. Osoba ucząca się języka polskiego jako obcego najczęściej robi to pod kierunkiem lektora. I to jego zadaniem powinno być pokazanie owej podwójnej normy, opatrzenie odpowiednim komentarzem frekwencyjnym wariantywnych zjawisk w języku. Odwołajmy się raz jeszcze do metafor zaproponowanych przez M. Steciąg. Można oczekiwać, że jako przewodnik po języku polskim nauczyciel będzie nie tyle przedstawiał fakty, ale uwrażliwiał na zjawiska językowe. „Zadanie języ- 
koznawców polegałoby więc na poradnictwie, a nie egzekwowaniu nakazów czy zakazów" - jak pisała przed laty Halina Satkiewicz (Satkiewicz 1995, 41).

$\mathrm{Na}$ koniec raz jeszcze odwołam się do wypowiedzi wspomnianej już studentki z Niemiec. Podczas jednych z zajęć zapytała, dlaczego ucząc obcokrajowców jedynie tego, co potoczne, ograniczamy ich możliwość poznania. Być może szansa wyboru między normą wysoką a użytkową stanowiłaby rozszerzenie tych możliwości. Z. Kaleta w jednym ze swoich artykułów przywołuje liczne przykłady struktur językowych charakterystycznych dla Polaków na Wschodzie, które mieszczą się w normie językowej, jednak nie należą do częstych. Badaczka pisze: ,(...) stanowisko uznające obie struktury za równouprawnione i normatywne jest wielce użyteczne i nauczyciel powinien się na nim oprzeć, pamiętając jednak o konieczności wprowadzenia dwóch poprawnych wariantów (...)., bo obydwa studenci będą spotykać w tekstach (...). Wiedza [studentów] z zakresu języka polskiego (...) powinna zawierać nie tylko zbiór reguł gramatyczno-leksykalnych, reprezentujących normę, lecz również pojęcie o wariantywności języka (...)" (Kaleta 1995, 88).

\section{BIBLIOGRAFIA}

Bańko M., 2008, O normie i błędzie, „Poradnik Językowy”, nr 5, s. 3-17.

Buttler D., 1985a, Teoria kultury języka i jej podstawowe pojęcia, „Prasa Techniczna”, nr 2.

Buttler D., 1985b, Zróżnicowanie współczesnej normy językowej, „Prasa Techniczna”, nr 3.

Buttler D., Kurkowska H., Satkiewicz H., 1971, Kultura języka polskiego. Zagadnienia poprawności gramatycznej, Warszawa.

Chomicz-Jung K., 1990, Norma glottodydaktyczna i jej rola w procesie glottodydaktycznym, „Przegląd Glottodydaktyczny", nr 11.

Dąbrowska A., Pasieka M., 2008, Błędy językowe w tekstach pisanych przez cudzoziemców - wybrane problemy zwiazane z klasyfikacją i ocena, w: A. Seretny, E. Lipińska (red.), Rozwijanie i testowanie biegłości w języku polskim jako obcym, Kraków.

Dembińska K., Małyska A., 2013, Start. Survival Polish. Podręcznik do nauki języka polskiego na poziomie A0, Warszawa.

Goszczyńska H., Magajewska M., 2012, Od przypadka do przypadka. Przewodnik dla cudzoziemców po fleksji imiennej języka polskiego, Łódź.

Grucza F., 1978, Z problematyki błędów obcojęzycznych, Warszawa.

Kaleta R., 2015, Polsko-białoruska lapsologia glottodydaktyczna, Kraków.

Kaleta Z., 1995, Norma językowa i uzus a nauczanie komunikacyjne studentów ze Wschodu, w: Ksztatcenie sprawności komunikacyjnej Polaków ze Wschodu, red. J. Mazur, Lublin, s. $83-88$.

Korzeniewska-Rogalewicz J., 1986, Btad leksykalny a dydaktyka języka obcego. Na materiale języka rosyjskiego, Warszawa.

Kurkowska H., 1977, Polityka językowa a zróżnicowanie społeczne współczesnej polszczyzny, w: W. Lubaś (red.), Socjolingwistyka 1. Polityka językowa, Katowice.

Madelska L., Warchoł-Schlottmann M., 2008, Odkrywamy język polski. Gramatyka dla uczacych (się) języka polskiego jako obcego, Kraków. 
Malota D., 2009, Witam. Der Polnischkurs, München.

Małolepsza M., Szymkiewicz A., 2010, Hurra!!! Po polsku 1, Kraków.

Markowski A., Kultura języka. Teoria. Zagadnienia leksykalne, Warszawa.

Mazur J., 1995, Kultura języka polskiego na Wschodzie w aspekcie podmiotowym i normatywnym, w: Kultura języka dziś, red. W. Pisarek, H. Zgółkowa, Poznań, s. 233-244.

Miodek J., 2001, O normie językowej, w: J. Bartmiński (red.), Współczesny język polski, Lublin.

Nocoń J., 2009, Podręcznik szkolny w dyskursie dydaktycznym - tradycja i zmiana, Opole.

Nowy stownik poprawnej polszczyzny, 1999, red. A. Markowski, Warszawa. (w tekście jako NSPP)

Piotrowska-Rola E., Porębska M., 2012, Polski jest cool. Seria do nauki języka polskiego jako obcego na poziomie A1, Lublin.

Podracki J., 2010, Poziomy normy językowej w nauczaniu języka polskiego jako obcego (JPJO), w: Kanon kultury w nauczaniu języka polskiego jako obcego, red. P. Garncarek, P. Kajak, A. Zieniewicz, Warszawa, s. 143-147.

Satkiewicz H., 1995, Norma współczesnego języka polskiego w odbiorze wspótczesnym, w: Kultura języka dziś, red. W. Pisarek, H. Zgółkowa, Poznań, s. 38-45.

Skorupa E., Lipińska E., 2010, Polski bez tajemnic. Język polski dla studentów niemieckojęzycznych, Kraków.

Steciąg M., 2014, Kim jest językoznawca normatywista dziś, „Poradnik Językowy”, nr 5.

Stelmach A., Stempek I., 2012, Polski, krok po kroku 2, Kraków.

Stempek I., Grudzień M., 2012, Polski, krok po kroku 1. Zeszyt ćwiczeń, Kraków.

Stempek I., Stelmach A., Dawidek S., Szymkiewicz A., 2013, Polski, krok po kroku 1, Kraków.

Szober S., 1937, Stownik ortoepiczny, Warszawa.

Szulc A., 1984, Podręczny stownik językoznawstwa stosowanego, Warszawa.

Uniwersalny słownik języka polskiego, 2006, red. S. Dubisz, Warszawa. (w tekście jako USJP).

\section{Beata Grochala}

\section{STANDARD POLISH VS. COMMON POLISH IN GLOTTODIDACTICS}

Keywords: standard Polish, common Polish, language correctness, Polish as a foreign language textbooks

Summary. The article presents the issue of the difference between standard and common Polish in glottodidactics. The analysis of a few randomly selected Polish as a foreign language textbooks shows various approaches to the problem. Therefore, the author concludes that there is a need to examine the role of both language varieties in teaching Polish as a foreign language. 